DOI: $10.15276 /$ ETR.02.2020.2

DOI: $10.5281 /$ zenodo.3976822

UDC: $658.152(477.74)$

JEL: E270, G310

\title{
FINANCIAL ASSURANCE AND EFFICIENCY OF INVESTMENTS ATTRACTION IN THE INFRASTRUCTURE DEVELOPMENT OF THE ODESSA REGION
}

\author{
ФІНАНСОВЕ ЗАБЕЗПЕЧЕННЯ ТА ЕФЕКТИВНІСТЬ ЗАЛУЧЕННЯ \\ ІНВЕСТИЦЙ У РОЗВИТОК ІНФРАСТРУКТУРИ ОДЕСЬКОЇ ОБЛАСТІ
}

\author{
Hanna O. Hratsiotova, Senior Lecturer \\ Odessa National Polytechnic University, Odessa, Ukraine \\ ORCID: 0000-0002-8594-489X \\ Email: savhenko965@gmail.com \\ Dmitry O. Pulcha \\ Odessa National Polytechnic University, Odessa, Ukraine \\ Email: dima.pulcha@gmail.com \\ Lev Tsekhmistrenko \\ Odessa National Polytechnic University, Odessa, Ukraine \\ ORCID: 0000-0001-6622-1795 \\ Email: levcehmistrenko@gmail.com
}

Received 14.01.2020

\footnotetext{
Грачіотова Г.О., Пульча Д.О., Цехмістренко Л. Фінансове забезпечення та ефективність залучення інвестицій у розвиток інфраструктури Одеської області. Науковометодична стаття.

В статті проаналізовано сучасний стан інвестиційної діяльності підприємств та інших установ Одеської області, досліджено проблеми, які існують в даній сфері та описано шляхи активізації інвестиційної діяльності підприємств в Одеській області. Запропоновано перелік найбільш значущих регіональних та загальнодержавних факторів, які позитивно впливають на інвестиційне середовище регіону. Використано комплексний підхід до обгрунтування подальших перспектив інвестування в національну економіку. Отримані результати дослідження $\epsilon$ підгрунтям для вирішення практичних проблем щодо залучення капітальних інвестицій як ключового фактора ефективного функціонування економіки України взагалі та Одеської області.

Ключові слова: інвестиції, інвестиційна діяльність, інвестиційний ринок, фінансування, інвестиційна політика, інвестиційне середовище

Hratsiotova H.O., Pulcha D.O., Tsekhmistrenko L. Financial Assurance and Efficiency of Investments Attraction in the Infrasrtucture Development of the Odessa Region. Scientific and methodical article.

The article analyzes the current state of enterprises investment activities and other institutions of the Odessa region, examines the problems that exist in this area and describes the ways to intensify the enterprises investment activities in the Odessa region. The list of the most significant regional and national factors which positively influence the region's investment environment is offered. A comprehensive approach to further prospects substantiation of investment in the national economy is used. The obtained research results are the basis for solving practical problems of capital investments attraction as a key factor in the effective functioning of Ukraine's economy in general and the Odessa region.

Keywords: invetments, investment activities, investment market, financing, investment policy, investment environment
}

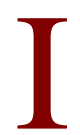

$\mathrm{n}$ modern socioeconomic conditions, the topic of financing and investment attractiveness of the Odessa region is quite relevant. The investment market in our country, including the Odessa region, is quite weak and shaky, because our country and all the cities are not experiencing glory days. In modern conditions, to increase the role of investment attractiveness of the Odessa region, it is necessary to develop the latest and most promising projects for their implementation.

\section{Analysis of recent researches and publications}

T.V. Maiorova [1], A.S. Zaverbnyi [2], I.O. Blank [3], I. V. Drahan [4], M.V. Trokhymchenko[5], T.V. Umanets [6], B.O. Yazliuk [7], Ya.D. Krupka [8], B. Ye. Peresada [9], V.V. Stadnyk [10] and others devoted their works to theoretical and methodological bases of investment activities.

\section{Unsolved aspects of the problem}

However, the issue of financial assurance and the effectiveness of investments attraction in the infrastructure development in the Odessa region remains immature.

The aim of the article is to develop implements to increase the investment attractiveness and the infrastructure development of the Odessa region.

\section{The main part}

The variety of the term «investments» in domestic and foreign literature is largely explained by the breadth of the essential features of this rather complex 
economic category. The theoretical framework for investment activities is based on the reproduction of joint capital as an investing of capital in economic branches at home and abroad. Let's consider the evolution of modern interpretations of this category.

A scientist I.O. Blank noted that investments mean the investing of capital in all its forms in various objects (implements) of economic activities for profit, as well as to achieve other economic and noneconomic effects, the implementation of which is based on market principles and time factors, risk and liquidity [11].

The nature of investments does not change depending on the viewpoint to consider them. Thus, according to A.I. Dieieva investments - are mostly temporarily free resources that can be invested in any field of activities; resources investment is accompanied by their alienation, therefore, the investment process is both a costly process.

Therefore, investments are complex synthetic concept that gives their social nature the manifestation versatility [12].

Thus, investments are understood as economic resources that are aimed at increasing the real joint capital, namely:

- expansion and modernization of production ;

— infrastructure creation of production ;

- creation of inventory holdings and reserves;

- creation of social infrastructure;

- personnel training and retraining;

- science and scientific service, etc. [4].

Thus, in our view, the term «investments» can be understood as an investing of capital in any industry or in the development of a city infrastructure. For the most part, investments involve, over time, a percentage of the contributed capital.

In the Article 1 of the Law of Ukraine "On Investment Activities" of 18 September, 1991, this concept is somewhat beyond the model of "incomeexpenditure", as it includes the society's social sphere. "Investments are all types of property and intellectual values that are invested in objects of entrepreneurial and other activities, as a result of which profit is generated or a social effect is achieved" [13].

There are many classifications of investments that are based on different consitions. Here are the most important of them.

They can be divided, for example, by the object on which the investment activities are directed:

- real investments - investings in construction, major maintenance;

- financial - investings in securities, including through investment funds, released proceeds of a loan, as well as leasing;

- speculative - trade in precious metals and securities.

Depending on the ownership form, certain investors' groups are formed. Another important criterion for deposits division into groups is the ownership form of investment resources. The search features and investments attraction in the project are based on this classification. Here one distiguishes:
- public - issued to ensure strategically important projects and may even fully cover project costs;

- private - deposits from private investors;

- foreign - deposits from individuals who are not the country's residents to which their investments are directed. This also includes deposits from foreign companies [5].

The investment policy of the Odessa region is built taking into account specific factors. When performing it, one tries to use the existing advantages to attract investors, both domestic and foreign. The Odessa region looks forward to the expansion of central budget subsidies to support the coal industry, agro-industrial enterprises or military-industrial complex, tries to mobilize its own resources through local taxes and other channels, as well as developing the private sector in order to attract its financial resources in the form of investments in the economy.

All the investments, on the whole, can be divided into two main components: real investments; financial investments.

Real investments involve direct investment in a particular area of activities (production, business, infrastructure, etc.). Funds are invested directly, without using various financial instruments.

Financial investments are money investments in various financing instruments, such as: stocks, bonds, bank deposits, precious metals, etc. The main purpose of financial investments is usually to obtain a certain income. But in some cases, such investments are made in order to acquire some influence on the investment object.

Investments classifications in foreign literature are of scientific and practical interest in terms of their potential for use in domestic practice. For example, a German professor Weinrich proposed the following investments classification:

1. Investments in relation to their application objects:

— investments in property (material investments) - investments in buildings, structures, equipment, materials inventory;

- nancial investments - acquisition of shares, bonds and other securities;

- intangible investments - investments in personnel training, research, advertising [3].

2. According to the nature of an investor's participation in the investment process, there are direct and indirect investments:

- direct investments - are characterized by the investor's direct participation in the choice of investment objects and putting up of money;

- indirect investments - are understood as investments mediated by third parties (investment or financial intermediaries).

3. Depending on the form of investors' ownership in the resources invested one distinguishes:

- public;

- private;

- mixed investments.

4. According to the regional sources of resources attraction one distinguishes: 
— foreign;

- domestic;

- mixed investments.

5. According to the investment period one distinguishes:

— short-term;

- medium-term;

- long-term investments [3].

The issue of investments attraction is considered on the example of the infrastructure of the Odessa region, namely: Odessa Sea Trade Port, Odessa International Airport, Odessa Rail Carrier, enterprises of the Odessa region.

Odessa Sea Trade Port is one of the largest ports in the Black Sea-Azov Basin, located in the northwestern part of the Black Sea at the intersection of trade routes of East and West. The port is a leader in terms of cargo handling among Ukrainian ports and one of the largest in the Black Sea. Odessa Sea Trade Port is connected by transport lines with more than 600 ports of 100 countries.
Odessa is a large railway hub, the centre of Odessa Rail Carrier, which is one of the largest rail carriers in Ukraine. An extensive network of railways connects Odessa with the cities of Ukraine and European countries. It provides transportation needs in Odessa, Mykolaiv, Kherson, Kirovohrad, Cherkasy and partly Vinnytsia regions, i.e. it serves an area of 138 thousand sq. $\mathrm{km}$. with a population of about 10 million people [7].

Odessa International Airport is one of the largest airports in Ukraine, connected by air with many cities around the world (Figure 1). The airport is capable of accomodating aircrafts of 4D code and below, helicopters of all types and lighter aircraft, has 57 parking spaces, equipped with air traffic control. The artificial runway has the dimensions of $2800 \times 56 \mathrm{~m}$, equipped with radio landing aids, lighting system, meteorological equipment, providing round-the-clock operation with meteorological minimum of ICAO category 1 from two courses [14].

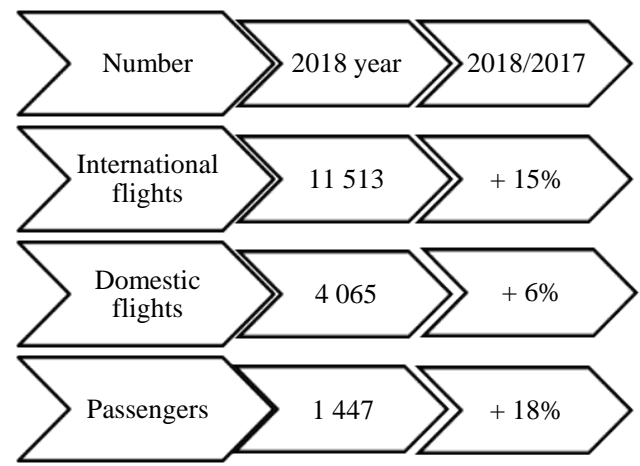

Figure 1. Number of Flights and Passenger Handling, 2017-2018. Source: the authors' own development

Odessa's peculiarity is that $49 \%$ of industrial products are sold here, almost $60 \%$ of capital and more than $40 \%$ of foreign direct investments are made, more than $60 \%$ of the region's retail turnover is formed, while more than $40 \%$ of the region's population lives (Figure 2) [14].

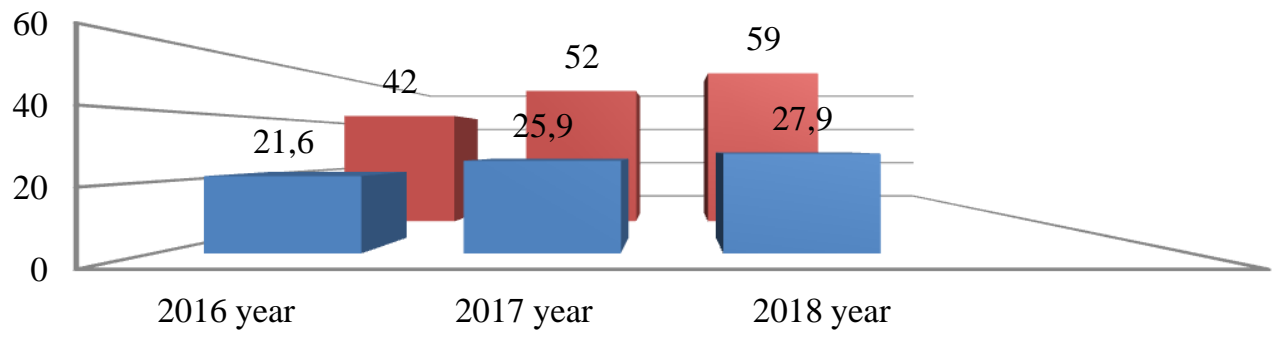

- Industrial products per person in Odessa

Industrial products per person in Ukraine

Figure 2. Industrial Products per Person for 2016-2018.

Source: the authors'own development

Odessa has a developed industrial complex, in the structure of its sales, which is dominated by the products of the process industry, which accounts for more than $60 \%$ of the industry volume (Table 1 ). 
Table 1. The Industrial Complex Industry for 2016-2018

\begin{tabular}{|l|c|c|c|}
\hline Billion, UAH & $\mathbf{2 0 1 6}$ & $\mathbf{2 0 1 7}$ & $\mathbf{2 0 1 8}$ \\
\hline $\begin{array}{l}\text { Supply of electricity, gas, } \\
\text { steam and air }\end{array}$ & 8.5 & 9.9 & 10.4 \\
\hline Machine buiding & 3.4 & 4.0 & 3.9 \\
\hline Rubber, plastic products & 2.0 & 2.6 & 3.3 \\
\hline Food products & 3.1 & 3.6 & 3.3 \\
\hline Metal products & 1.8 & 2.4 & 3.0 \\
\hline Water supply, waste & 0.8 & 1.0 & 1.3 \\
\hline Wood products & 0.4 & 0.4 & 0.5 \\
\hline Other & 1.6 & 2.0 & 2.5 \\
\hline
\end{tabular}

Source: compiled by autor on materials [14]

The developed transport network and the status of the economic centre of the country's south contribute to the consistently high foreign trade activities of Odessa enterprises. The geography of export and import of goods and services is expanding. The foreign commerce structure is differentiated both by product group and by countries (Table 2 ).

Table 2. Export and Import of Goods for 2016-2018

\begin{tabular}{|l|c|c|c|}
\hline \$ million & $\mathbf{2 0 1 6}$ & $\mathbf{2 0 1 7}$ & $\mathbf{2 0 1 8}$ \\
\hline Export of goods, services & 1207 & 1329 & 1330 \\
\hline Import of goods, services & 871 & 1125 & 1279 \\
\hline Foreign trade port & 2078 & 2454 & 2609 \\
\hline Trade surplus & +336 & +204 & +51 \\
\hline $\begin{array}{l}\text { The number of partner } \\
\text { countries }\end{array}$ & 169 & 158 & 161 \\
\hline
\end{tabular}

Source: compiled by autor on materials [14]

In Odessa the volume of allocations for financing activities in the transport sector, in the field of housing and communal services is increasing every year in order to increase its energy efficiency and introduction of energy efficient technologies. For which, among other things, funds from international financial institutions are involved [14].
Odessa has a developed industrial complex and the potential to prepare attractive offers for investors. The city can develop its traditional branches of process industries, transport, construction and logistics, in which significant amounts of investments have already been attracted. (Figure 3).

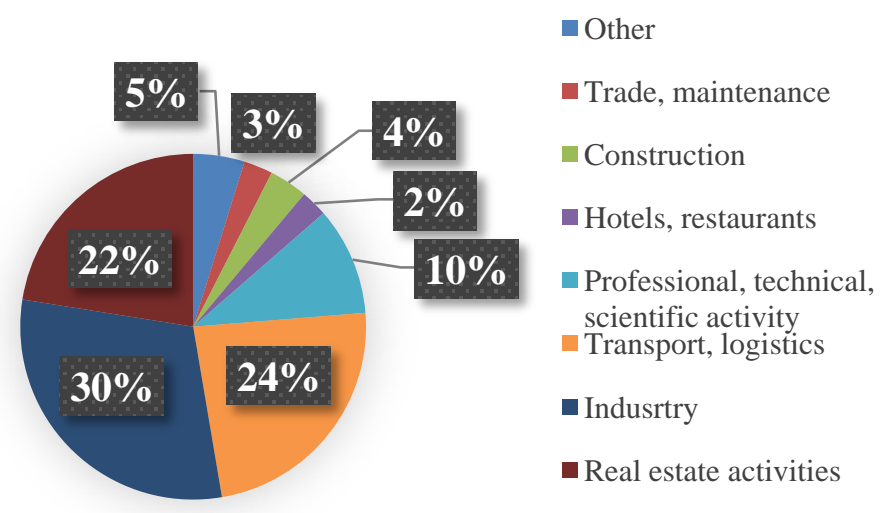

Figure 3. The Area of Investments in the Odessa Region Source: compiled by autor on materials [14]

As we can see from the figure 3 the most investments arrival in our city is accounted for by industry, real estate activities and transport. These are three most important sectors that attract investors, both foreign and domestic. In total, companies from
34 countries have invested in the city's economy, most of them from Europe - 21. The growth of business activity, tourist flow allow Odessa to increase the city budget evenues provide a more 
flexible spending policy and increase spending on urban infrastructure (Table 3) [14]. Table 3. The Budget Revenues and Expenditures of the Odessa region city

\begin{tabular}{|l|c|c|c|}
\hline \multicolumn{1}{|c|}{ Million, UAH } & $\mathbf{2 0 1 6}$ & $\mathbf{2 0 1 7}$ & $\mathbf{2 0 1 8}$ \\
\hline Budget revenues & 7422.1 & 9335.2 & 10754.0 \\
\hline Budget expenditures & 7410.2 & 10264.2 & 11349.0 \\
\hline Deficit / proficit & 11.9 & -928.9 & -595.0 \\
\hline
\end{tabular}

Source: compiled by autor on materials [14]

As you can see from the table 3, every year since 2016 there has been a budget deficit (our expenditures are greater than revenues) in our city. It is very bad for cities, if we also plan to attract investments.
The key sources of pumping up the budget are personal income tax, local taxes and fees, revenues from the administrative services provision and privatization [14].

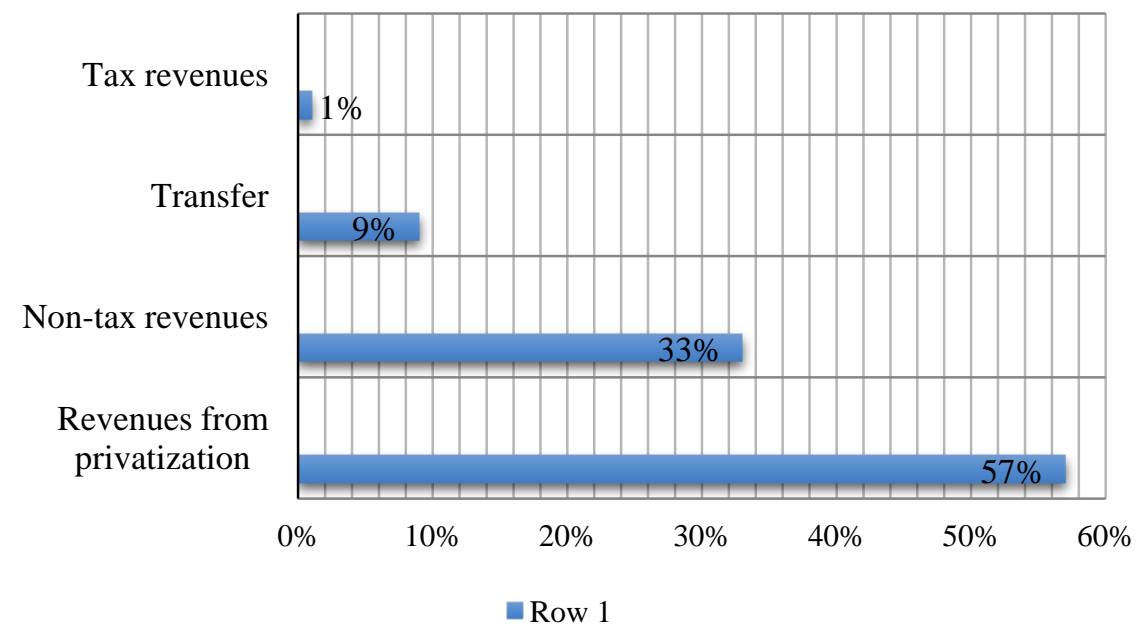

Figure 4. Pumping up the Budget of Odessa

Source: of the authors' own development

The Figure 4 see shows that the largest revenues to the budget are taxes, and the smallest ones - are revenues from privatization, only $1 \%$.

Pumping up the budget is differentiated both by industries and by taxpayers. Odessa City Council together with utilities are active participants in the borrowing market. Funds are raised from Ukrainian banks and international financial organizations for the infrastructure projects implementation under the city authorities' guarantee.

\section{Conclusions}

Thus, the article defines the essence of regional investment policy, which means the process, mainly subjective, which determines the territorial features of the region. In practice, it represents the actions of state and local authorities and management to develop the investment process in the region, related to improving the regulatory framework, providing preferences for the most effective and significant investment projects in the region, investment infrastructure development, ensuring the enterprises safety. For any country's administrative unit, it is important to develop entrepreneurship as a key factor in the economy development.

In order to improve the investment climate in the Odessa region, it is necessary to:

- to continue the investment package formation, which would include industrial and social infrastructure;

— in order to facilitate the investment projects implementation to combine the region's intellectual and entrepreneurial potential;

— in order to publish the investment attractiveness of the region's certain territories to develop the rating of their investment attractiveness.

\begin{abstract}
Summarizing the analysis results, let us determine if the investments have always been and still are the dominant factor in the economy development, both in the country and in the regions. In our opinion the Odessa region is one of the best cities in our country, it has all the features of life: the sea, the fields, the monuments of architecture. All this is the city's business card. One of the most important conditions for effective management of the investments development is sound planning of the investment process. Development and presentation of the latest plans, projects, for improvement and attractiveness of the city for investors and visitors from other
\end{abstract}


regions and countries. The obtained research results are the basis for solving practical problems of capital investments attraction as a key factor in the effective functioning of Ukraine's economy in general and Odessa region.

\section{Список літератури}

1. Майорова Т.В. Інвестиційна діяльність: навч. посібн. / Т.В. Майорова. - К.: Центр навчальної літератури, 2004. - 376 с.

2. Завербний А.С. Управління інвестиційною діяльністю на засадах функціонального підходу / А.С. Завербний // Економіка та прогнозування. - 2016. - № 5. - С. 34-39.

3. Бланк I.О. Управління фінансами підприємств / І.О. Бланк, Г.В. Ситник. - К.: КНТЕУ, 2006. - 780 c.

4. Драган І.В. Оцінка сучасного стану залучення іноземних інвестицій в Україні / І.В. Драган // Фондовий ринок, 2016. - № 4. - С. 22-27.

5. Трохимченко М.В. Оцінка інвестиційної привабливості регіонів України / М.В. Трохимченко // Економіка України. - 2015. - № 12. - С. 43-45.

6. Уманець Т.В. Оцінка інвестиційної привабливості регіону за допомогою інтегральних індексів / Т.В. Уманець // Економіка України. - 2014. - № 7. - С. 52-54.

7. Язлюк Б.О. До питання методики оцінки економічної ефективності реальних інвестиційних проектів / Б.О. Язлюк // Вісник Східноукраїнського національного університету ім. Володимира Даля. - Луганськ. - 2016. - № 12. - С. 214-219.

8. Крупка Я.Д. Основи економічної теорії. Підручник. / Я.Д. Крупка. - Київ: Атіка, 2003. - 480 с.

9. Пересада А.А. Інвестиційний аналіз. Підручник / А.А. Пересада, С.В. Онікієнко, С.В. Коваленко. - Київ: КНЕУ, 2003. - 134 с.

10. Стадник В.В. Теоретико-методологічні основи інвестування розвитку регіону / В.В. Стадник, Н.I. Непогодіна // Актуальні проблеми економіки. - 2016. - № 1. - С. 60-69.

11. Про інвестиційну діяльність: Закон України від 18.09.1991р. № 1560-XII // Відомості ВРУ від 19.11.1991. № 47. - стаття 646.

12. Деева А.И. Инвестиции: учеб. пособие / А.И. Деева; Московская академия экономики и права. М. Экзамен, 2014. - 318 с.

13. Експрес-випуск Державна служба статистики України Переробка винограду та виробництво виноматеріалів у 2015 році [Електронний ресурс]. - Режим доступу: http:// http://ukrstat.org.ua.

14. Інвестиційний паспорт Одеської області. - Режим доступу: http://gestyy.com/e0qqA8.

15. Формування стратегії безпекоорієнтованого управління інноваційно-інвестиційним кліматом регіону - с.132-163/ С.В.Філиппова, Л.О.Волощук, К.В.Ковтуненко, Ю.В.Ковтуненко. // Підрозділ п.3.1 у кол. моногр. Інноваційно-інвестиційний клімат Українського Причорномір'я: стан і безпекоорієнтований розвиток: кол. моног./ за ред.. М.М.Меркулова. - Рига, Латвія: «BaltijaPublishing». - 2019. - 308 с. - Режим доступу: https://oldiplus.ua/downloads/451.pdf ISBN 978-9934-571-93-0.

\section{References}

1. Maiorova T.V. (2004). Investment activity: textbook. manual. Kyiv: Center for Educational Literature [in Ukranian].

2. Zaverbnyi A.S. (2016). Management of investment activity on the basis of functional approach. Economics and forecasting, 5, 34-39 [in Ukranian].

3. Blank I.O. \& Sytnyk H.V. (2006). Enterprises financial management. K.: KNTEU. [in Ukranian].

4. Drahan I.V. (2016). Estimation of the current state of foreign investment in Ukraine. Stock Market,4, 22-27 [in Ukranian].

5. Trokhymchenko M.V. (2015). Estimation of investment attractiveness of regions of Ukraine. Economy of Ukraine, 12, 43-45 [in Ukranian].

6. Umanets T.V. (2014). Estimation of investment attractiveness of the region with the help of integral indices. Economy of Ukraine, 7, 52-54 [in Ukranian].

7. Yazliuk B.O. (2016). On the issue of methods for assessing the economic efficiency of real investment projects. Bulletin of the East Ukrainian National University named after Vladimir Dahl, 12, 214-219. Luhansk. [in Ukranian].

8. Krupka Ya.D. (2003). Foundations of economic theory. Textbook. Kyiv: Atika. [in Ukranian].

9. Peresada A.A., Onikienko S.V. \& Kovalenko S.V. (2003). Investment analysis. Textbook. Kyiv: KNEU [in Ukranian]. 
10. Stadnik V.V. \& Nepogodina N.I. (2016). Theoretical and methodological foundations of investing in the development of the region. Actual problems of economy, 1, 60-69 [in Ukranian].

11. On investment activity: Law of Ukraine of September 18, 1991. № 1560-XII. Information of the Verkhovna Rada of 19.11.1991, 47. - Article 646 [in Ukranian].

12. Deeva A.I. \& Moscow Academy of Economics and Law. (2014). Investments: textbook. allowance. M. Exam. [in Russian].

13. Express issue of the State Statistics Service of Ukraine Processing of grapes and production of wine materials in 2015. http://ukrstat.org.ua. Retrieved from http://ukrstat.org.ua [in Ukranian].

14. Investment passport of Odessa region. http://gestyy.com. Retrieved from http://gestyy.com/e0qqA8 [in Ukranian].

15. Filippova S.V., Voloshchuk L.O., Kovtunenko K.V., Kovtunenko Y.V. (2019). Formation of strategy of security-oriented management of innovation and investment climate of the region. Innovation and investment climate of the Ukrainian Black Sea region: state and security-oriented development: col. monologue. M.M. Merkulova (ed.). Riga, Latvia: BaltijaPublishing. Retrieved from https://oldiplus.ua/downloads/451.pdf ISBN 978-9934-571-93-0 [in Ukranian].

\section{Посилання на статтю:}

Hratsiotova H.O. Financial Assurance and Efficiency of Investments Attraction in the Infrasrtucture Development of the Odessa Region / H.O. Hratsiotova, D.O. Pulcha, L. Tsekhmistrenko // Економіка: реалії часу. Науковий журнал. - 2020. - № 2 (48). - C.15-21. - Режим доступу до журн.: https://economics.opu.ua/files/archive/2020/No2/15.pdf.

DOI: 10.15276/ETR.02.2020.2. DOI: 10.5281/zenodo.3976822.

\section{Reference a Journal Article:}

Hratsiotova H.O. Financial Assurance and Efficiency of Investments Attraction in the Infrasrtucture Development of the Odessa Region / H.O. Hratsiotova, D.O. Pulcha, L. Tsekhmistrenko // Economics: time realities. Scientific journal.-2020. - № 2 (48). - P. 15-21. - Retrieved from https://economics.opu.ua/files/archive/2020/No2/15.pdf. DOI: 10.15276/ETR.02.2020.2. DOI: 10.5281/zenodo.3976822. 